\title{
Pengembangan Bahan Ajar Mikrobiologi Menggunakan Jurnal Ilmiah Sebagai Sumber Belajar Di Universitas Islam Negeri Alauddin Makassar
}

\author{
Syahruni Karim \\ Prodi Pendidikan Biologi STKIP Pembangunan Indonesia Makassar \\ syahruni.kr@gmail.com
}

\begin{abstract}
ABSTRAK
Penelitian ini merupakan penelitian pengembangan modul pembelajaran Mikrobiologi untuk mahasiswa semester VI di Universitas Negeri Alauddin Makassar. Modul pengembangan yang digunakan dalam penelitian ini mengacu pada model Borg and Gall (1983) terdiri atas 6 tahap.Tujuan penelitian ini adalah untuk menghasilkan bahan ajar Mikrobiologi yang valid, praktis, dan efektif. Penelitian ini dilaksanakan di Universitas Islam Negeri Alauddin Makassar dengan subjek penelitian meliputi satu kelas yang terdiri 27 mahasiswa. Pengumpulan data dilakukan melalui proses validasi modul pembelajaran, satuan acara perkuliahan, respon mahasiswa dan tes hasil belajar. Hasil uji coba lapangan menunjukkan bahwa modul pembelajaran Mikrobiologi memenuhi kriteria efektif, yakni: (1) aktivitas mahasiswa berjalan sesuai dengan yang diharapkan (2) respon mahasiswa dan respon pengajar memenuhi kriteria respon positif yaitu melebihi 50\%, dan (3) hasil belajar mahasiswa memenuhi penilaian acuan pembelajaran yaitu rata-rata 75,26 atau 88,89\%. Berdasarkan hasil uji coba menunjukkan bahwa modul pembelajaran Mikrobiologi dengan jurnal ilmiah sebagai sumber belajar memenuhi kriteria kevalidan, kepraktisan dan keefektifan.
\end{abstract}

Kata Kunci: Bahan ajar, jurnal ilmiah, model pembelajaran Borg and Gall (1983)

\section{PENDAHULUAN}

Berkembangnya teknologi dan dunia industri Ilmu pengetahuan dan teknologi (IPTEK) dalam dunia pendidikan memegang peranan penting dalam mewujudkan pembangunan nasional. Melalui pendidikan, pembentukan dan peningkatan kualitas sumber daya manusia dapat dilakukan demi terbentuknya satu generasi penerus yang akan membangun bangsa dan negara ke arah yang lebih baik. Oleh karena itu, program pembentukan sumber daya manusia perlu di tingkatkan melalui penyelenggaraan pendidikan yang dilaksanakan secara sistematis dan berkesinambungan.

Pendidikan harus diberikan kepada semua warga negara tanpa terkecuali sebagaimana diamanatkan dalam UndangUndang 1945, sehingga semua warga negara dapat berpartisipasi dalam pembangunan nasional dan memungkinkan setiap warga negara untuk mengembangkan potensi yang dimilikinya secara optimal (Widodo, 2008). Dalam Undang-Undang Sistem Pendidikan Nasional No.20 Tahun 2003 pasal 3 disebutkan pendidikan nasional bertujuan agar peserta didik menjadi manusia yang beriman dan bertaqwa kepada Tuhan Yang Maha Esa, berakhlaq mulia, sehat, berilmu, cakap, kreatif, mandiri, dan menjadi warga negara yang demokratis dan bertanggung jawab. Berdasarkan hal tersebut, pemerintah serta pendidik mempunyai peranan penting dalam mengembangkan potensi peserta didik.

Upaya untuk mewujudkan pendidikan nasional dapat dicapai dengan berbagai cara, salah satunya mengembangkan program bahan ajar agar pembelajaran dapat berlangsung secara efektif, efisien, dan memiliki daya tarik. Sesuai dengan Degeng (1993) bahwa dalam rangka meningkatkan kualitas pembelajaran, perekayasaan metode pembelajaran meliputi strategi pengorganisasian, strategi penyampaian, dan strategi pengelolaan pembelajaran harus secara terus menerus diupayakan.

Pemilihan bahan ajar pada umumnya sering ditemukan masalah dalam menentukan jenis materi/analisis materi, sumber belajar yang masih mengutamakan buku cetak yang belum tentu relevan dengan tujuan pembelajaran, konstruksi kurikulum, ruang lingkup, urutan penyajian, dan perlakuan terhadap materi pembelajaran (Faizah, 2010). Hal tersebut sejalan dengan masalah yang dihadapi di tempat penelitian bahwa kecenderungan pendidik masih menitikberatkan pada bahan ajar berupa buku 
teks. Berdasarkan analisis materi yang dilakukan, bahan ajar yang digunakan memiliki keterbatasan pada konstruksi isi, sehingga untuk mendukung isi materi pembelajaran dibutuhkan sumber belajar alternatif lainnya, salah satunya yaitu pemanfaatan jurnal ilmiah. Jurnal ilmiah yang dipergunakan adalah artikel ilmiah yang menyajikan teori, hasil pemikiran, serta contoh-contoh yang berkaitan dengan materi. Permasalahan tersebut didukung oleh hasil angket pra-penelitian, yaitu terdapat $78 \%$ mahasiswa menyatakan buku ajar yang digunakan dalam kegiatan pembelajaran memiliki keterbatasan dari aspek pemberian contoh yang berkaitan dengan materi, 74\% penjabaran atau konstruksi isi buku ajar dinyatakan kurang menarik, sementara itu $70 \%$ jurnal ilmiah dapat dijadikan sebagai sumber belajar inovatif, dan $76 \%$ sangat setuju adanya bahan ajar berupa modul yang menggunakan sumber belajar dari buku dan jurnal ilmiah.

Dengan demikian khususnya dalam pembelajaran mikrobiologi atau mata kuliah wajib bagi mahasiswa semester VI (enam) jurusan pendidikan biologi UIN Alauddin Makassar, maka dibutuhkan bahan ajar spesifik, yang dirancang sesuai karakteristik kebutuhan, lingkungan pembelajaran, dan perkembangan mahasiswa, dengan tujuan dapat memudahkan mahasiswa dalam memahami isi materi dan dapat membantu kesulitan dalam proses kegiatan pembelajaran. Sehubungan dengan itu rumusan masalah yang dikaji dalam penelitian ini yaitu bagaimana kualitas (kevalidan, kepraktisan, dan keefektifan) modul Mikrobiologi dengan menggunakan jurnal ilmiah sebagai sumber belajar.

\section{METODE PENELITIAN}

Penelitian ini termasuk dalam jenis penelitian dan pengembangan atau Research and Development (R\&D). Model yang digunakan adalah Borg and Gall (1983). Adapun definisi operasional dalam penelitian ini yaitu 1) Pengembangan bahan ajar mikrobiologi adalah merancang dan mengembangkan informasi mikrobiologi yang spesifik, dan mudah dipahami, 2) Jurnal ilmiah adalah kajian ilmiah dari disiplin ilmu yang menyajikan teori, contoh, serta hasil pemikiran dari para ahli yang berkaitan dengan materi yang dikembangkan, 3) Sumber belajar adalah bahan informasi yang disajikan dan dikemas dalam bentuk modul, yang membantu mahasiswa dalam proses pembelajaran dalam mencapai kompetensi. Pengembangan ini menggunakan sumber belajar dari jurnal ilmiah yang berkaitan dengan materi dan dipadukan dengan buku-buku mikrobiologi untuk mendukung kontruksi isi modul.

Prosedur penelitian mengacu pada model pengembangan Borg and Gall (1983) terdiri atas 6 tahap yang disesuaikan dengan kebutuhan peneliti, yaitu 1) Tahap pengumpulan data awal, 2) Tahap perencanaan, 3) Tahap pengembangan draf produk, 4)Tahap uji lapangan, 5) Tahap revisi hasil uji coba, dan 6) Tahap penyempurnaan produk akhir.

Teknik analisis data dalam penelitian ini menggunakan instrument yang dianalisis secara kuantitatif dan diarahkan untuk mengetahui kevalidan, kepraktisan, dan keefektifan modul. Data yang diperoleh dari hasil validasi oleh para ahli dianalisis untuk mengetahui kevalidan dan kelayakan modul dengan menggunakan jurnal ilmiah sebagai sumber belajar.

Data hasil validasi para ahli untuk format judul modul pembelajaran dianalisis dengan mempertimbangkan penilaian, masukan, komentar, dan saran-saran dari validator. Analisis data kevalidan dilakukan terhadap semua format modul pembelajaran dan semua instrumen pengumpulan data penelitian. Validitas format modul ditentukan dengan mencocokkan rata-rata total validitas seluruh butir penilaian dengan standar validitas pada Tabel 1. berikut ini.

Tabel 1. Standarisasi perangkat pembelajaran

\begin{tabular}{cc}
\hline Kategori & Interval \\
\hline Sangat Valid (SV) & $3,5 \leq \mathrm{KP}<4$ \\
Valid (V) & $2,5 \leq \mathrm{KP}<3,5$ \\
Cukup Valid (CV) & $1,5 \leq \mathrm{KP}<2,5$ \\
Tidak Valid (TV) & $0,5 \leq \mathrm{KP}<1,5$ \\
\hline
\end{tabular}

(Nurdin, 2007) 
Selanjutnya kegiatan yang dilakukan pada analisis data kevalidan perangkat pembelajaran meliputi:

a. Melakukan rekapitulasi hasil penilaian ahli ke dalam tabel yang meliputi; aspek $\left(\mathrm{A}_{\mathrm{i}}\right)$, kriteria $\left(\mathrm{K}_{\mathrm{i}}\right)$, hasil penilaian validator $\left(\mathrm{V}_{\mathrm{ji}}\right)$.

b. Mencari rerata hasil penilaian ahli untuk setiap kriteria dengan rumus :

Keterangan:

$\mathrm{K}_{\mathrm{i}} \quad=$ rerata kriteria ke- $\mathrm{i}$

$\mathrm{Vji}=$ skor hasil penilaian terhadap kriteria ke-i oleh penilai ke-j
n
$=$ banyaknya penilai

c. Mencari rerata tiap aspek dengan rumus:

Keterangan:

$\mathrm{A}_{\mathrm{i}} \quad=$ rerata kriteria ke-i

Kij $=$ rerata untuk aspek ke-i kriteria ke-j d. Mencari rerata total dengan rumus:

Keterangan:

$\begin{array}{ll}\mathrm{X} & =\text { rerata total } \\ \mathrm{A}_{\mathrm{i}} & =\text { rerata aspek ke- } \mathrm{i} \\ \mathrm{n} & =\text { banyaknya aspek }\end{array}$

e. Menentukan kategori validasi setiap kriteria $\mathrm{K}$, atau rerata aspek $\mathrm{A}_{\mathrm{i}}$, atau rerata total $\mathrm{X}$ dengan kategori validasi yang telah ditetapkan.

Analisis data kepraktisan diperoleh dari pengamatan dua observer terhadap keterlaksanaan dalam menggunakan modul pembelajaran meliputi pengamatan pengelolaan pembelajaran yang dilakukan untuk mengetahui kemampuan pengajar melaksanakan setiap aspek pembelajaran mata kuliah Mikrobiologi. Nilai kemampuan pengajar (KP) akan dikonfirmasikan dalam interval kategori pada tabel berikut ini:

Tabel 2. Standarisasi Kepraktisan Kemampuan Pengajar

\begin{tabular}{cc}
\hline Kategori & Interval \\
\hline Sangat Tinggi & $3,5 \leq \mathrm{KP}<4$ \\
Tinggi & $2,5 \leq \mathrm{KP}<3,5$ \\
Cukup Tinggi & $1,5 \leq \mathrm{KP}<2,5$ \\
\hline
\end{tabular}

(Sumber: Nurdin, 2007)

Analisis terhadap keefektifan modul pembelajaran Mikrobiologi dengan jurnal ilmiah sebagai sumber belajar didukung oleh hasil analisis data dari tiga komponen keefektifan, yaitu berikut ini :
1) Aktivitas mahasiswa

Aktivitas mahasiswa dalam proses kegiatan pembelajaran dikatakan efektif jika memenuhi kriteria keefektifan $>55 \%$. Berikut ini tabel interval aktivitias mahasiswa dalam pembelajaran.

Tabel 3. Interval Penilaian Aktivitas Mahasiswa

\begin{tabular}{cc}
\hline Kategori & Interval \\
\hline Sangat Tinggi & $85 \%-100 \%$ \\
Tinggi & $70 \%-84 \%$ \\
Cukup & $55 \%-69 \%$ \\
Rendah & $40 \%-54 \%$ \\
Sangat Rendah & $20 \%-39 \%$ \\
\hline
\end{tabular}

(Sumber: Nurdin, 2007)

2) Respon mahasiswa dan pengajar

Data respon mahasiswa dan respon pengajar diperoleh dari angket terhadap modul pembelajaran, kemudian dianalisis dengan analisis persentase meliputi, 1) menghitung rata-rata skor respon setiap responden berdasarkan respon terhadap seluruh butir pertanyaan, 2) mengonfirmasi rata-rata respon setiap responden dengan kategori respon, 3) menghitung banyaknya respon yang termasuk kategori, dan 4) menghitung persentase respon. Respon tersebut dikatakan memenuhi kriteria keefektifan jika berada minimal dalam kategori 
positif atau mendapatkan respon positif atau baik lebih dari 50\%.

3) Hasil belajar

Hasil belajar mahasiswa secara inidividu dianalisis menggunakan analisis persentase skor yang benar dari seluruh butir tes yang diberikan. Penentuan keberhasilan belajar mahasiswa akan dikelola berdasarkan pada Penilaiaan Acuan Patokan (PAP) yang digunakan untuk mengetahui penguasaan terhadap materi pembelajaran. Acuan patokan yang harus dicapai mahasiswa pada mata kuliah mikrobiologi yaitu dengan nilai 70 . Penilaian Acuan Patokan (PAP) dalam bentuk rentang skor disajikan pada tabel berikut ini:

Tabel 4. Interval Penilaian Acuan Patokan

\begin{tabular}{cc}
\hline Kategori & Interval \\
\hline Tinggi sekali & skor $80-100$ \\
Tinggi & skor $70-79$ \\
Sedang & skor $60-69$ \\
Rendah & skor $45-59$ \\
Sangat Rendah & skor $<44$ \\
\hline
\end{tabular}

(Sumber: Mansur, 2009)

Untuk menentukan nilai terhadap hasil belajar digunakan rumus berikut ini:

$$
\text { Nilai }=\quad \text { X } 100
$$

(Sudijono, 2012)

\section{HASIL \& PEMBAHASAN}

Pengembangan modul penelitian ini bertujuan untuk menghasilkan modul pembelajaran yang valid, praktis, dan efektif sehingga layak digunakan dalam kegiatan pembelajaran.
Adapun hasil dari pengembangan modul dengan menggunakan jurnal sebagai sumber belajar sebagai berikut:

\section{Kevalidan}

a. Modul

Aspek-aspek yang diperhatikan dalam memvalidasi modul yaitu cakupan isi, penggunaan bahasa, tampilan modul, sajian, kelengkapan komponen, dan latihan. Berikut hasil penilaian pengembangan modul pembelajaran disajikan pada Tabel 5 .

Tabel 5. Hasil Validasi Modul Pembelajaran

\begin{tabular}{llll}
\hline No & Aspek & $\begin{array}{l}\text { Rerata }(\boldsymbol{x}) \\
\text { penilaian validator }\end{array}$ & Kriteria \\
\hline 1. & Cakupan Isi & 3,3 & Valid \\
\hline 2. & Penggunaan Bahasa & 3,9 & Sangat Valid \\
\hline 3. & Tampilan Modul & 3,6 & Sangat Valid \\
\hline 4. & Sajian & 3,5 & Valid \\
\hline 5. & Kelengkapan komponen & 4 & Sangat Valid \\
\hline 6. & Latihan & 3,8 & Sangat Valid \\
\hline
\end{tabular}

Ditinjau dari keseluruhan aspek modul dinyatakan memenuhi kriteria kevalidan dengan sedikit revisi. b. Satuan acara perkuliahan (SAP)

Secara garis besar aspek-aspek yang diperhatikan dalam memvalidasi satuan acara perkuliahan (SAP) yaitu, format SAP, materi yang disajikan, dan bahasa. Hasil validasi SAP disajikan sebagai berikut: 
Tabel 6. Hasil Validasi SAP

\begin{tabular}{llll}
\hline No & Aspek & $\begin{array}{l}\text { Rata-rata }(\mathrm{x}) \\
\text { Nilai Validator }\end{array}$ & Kriteria \\
\hline 1. & Format SAP & 3,70 & Sangat valid \\
2. & Sajikan materi & 3,75 & Sangat valid \\
3. & Bahasa & 3,75 & Sangat valid \\
\hline
\end{tabular}

c. Tes hasil belajar

Validasi tes hasil belajar secara garis besar mencakup materi soal, konstruksi, bahasa dan waktu. Penilaian ahli terhadap aspek tersebut disajikan pada Tabel 7. berikut ini.

Tabel 7. Hasil Validasi Tes Hasil Belajar

\begin{tabular}{llll}
\hline No & Aspek & $\begin{array}{l}\text { Rata-rata (x) Nilai } \\
\text { Validator }\end{array}$ & Kriteria \\
\hline 1. & Materi soal & 3,5 & Sangat valid \\
2. & Konstruksi & 4 & Sangat valid \\
3. & Bahasa & 4 & Sangat valid \\
4. & Waktu & 4 & Sangat valid \\
\hline
\end{tabular}

Hasil penilaian validasi oleh ahli terhadap tes hasil belajar, rata-rata termasuk dalam kategori "sangat valid" sehingga dapat digunakan.

\section{Kepraktisan}

Kegiatan yang dilakukan pada tahap ini adalah mengumpulkan data dari hasil uji coba kepraktisan dan keefektifan. Adapun hasil analisis kepraktisan dalam penggunaan modul dapat dilihat dari cara pengelolaan pembelajaran pada Tabel 8 . berikut ini:

Tabel 8. Hasil Kemampuan Pengajar Dalam Mengelola Pembelajaran

\begin{tabular}{llll}
\hline No & Aspek pengamatan & $\begin{array}{l}\text { Rata-rata(x) } \\
\text { pengamatan }\end{array}$ & Kriteria \\
\hline 1 & Kegiatan awal & 3,75 & Sangat tinggi \\
2 & Kegiatan inti & 3,61 & Sangat tinggi \\
3 & Kegiatan Akhir & 3,83 & Sangat tinggi \\
4 & Suasana Kelas & 3,6 & Sangat tinggi \\
\hline
\end{tabular}

Secara keseluruhan aspek kegiatan pembelajaran rata-rata berada pada kategori sangat tinggi. Hasil ini menunjukkan bahwa modul mikrobiologi dengan menggunakan jurnal ilmiah sebagai sumber belajar memenuhi kriteria kepraktisan.

\section{Keefektifan}

Hasil data keefektifan meliputi pengamatan aktivitas mahasiswa, respon mahasiswa dan guru serta tes hasil belajar Adapun dekskripsi dari hasil keefektifan dalam penelitian ini, yaitu:

a. Pengamatan aktivitas mahasiswa

Pengamatan aktivitas mahasiswa diperoleh berdasarkan observasi selama proses kegiatan pembelajaran berlangsung. Hasil dari analisis aktivitas mahasiswa disajikan pada Tabel 9 . Sebagai berikut. 
Tabel 9. Hasil Analisis Pengamatan

Aktivitas Mahasiswa

\begin{tabular}{|l|l|l|l|l|l|l|l|}
\hline \multirow{2}{*}{$\begin{array}{l}\text { Kategori } \\
\text { Aktivitas } \\
\text { Mahasiswa }\end{array}$} & \multicolumn{2}{l|}{ Pertemuan I } & \multicolumn{2}{l|}{ Pertemuan II } & \multicolumn{2}{l|}{ Pertemuan III } & Rata-rata \\
\cline { 2 - 9 } & F & $\%$ & f & $\%$ & F & $\%$ & $X$ \\
\hline 1 & 24 & 88.89 & 22 & 81.48 & 23 & 85.19 & 85.18 \\
\hline 2 & 11 & 40.74 & 16 & 59.26 & 27 & 100 & 66.70 \\
\hline 3 & 10 & 37.04 & 10 & 37.04 & 12 & 44.44 & 40.00 \\
\hline 4 & 12 & 44.44 & 8 & 29.63 & 6 & 22.22 & 32.10 \\
\hline 5 & 10 & 37.04 & 7 & 25.93 & 9 & 33.33 & 32.10 \\
\hline 6 & 2 & 40.00 & 3 & 60.00 & 4 & 100 & 66.66 \\
\hline Total & 69 & 288.15 & 66 & 293.34 & 81 & 385.18 & 322.74 \\
\hline
\end{tabular}

Keterangan:

1. Mahasiswa aktif memperhatikan pembelajaran

2. Mahasiswa aktif bekerja sama dalam kelompok

3. Mahasiswa aktif berdiskusi

4. Mahasiswa aktif mengajukan pertanyaan

5. Mahasiswa aktif menjawab/menanggapi pertanyaan

6. Membuat kesimpulan

b. Respon Mahasiswa

Hasil respon mahasiswa bertujuan untuk mengetahui sejauh mana modul mikrobiologi dengan menggunakan jurnal ilmiah sebagai sumber belajar dilaksanakan. Hasil respon mahasiswa semester VII Universitas Islam
Negeri Alauddin terhadap modul mikrobiologi dengan menggunakan jurnal ilmiah sebagai sumber belajar dapat dilihat pada Gambar 1 . sebagai berikut.

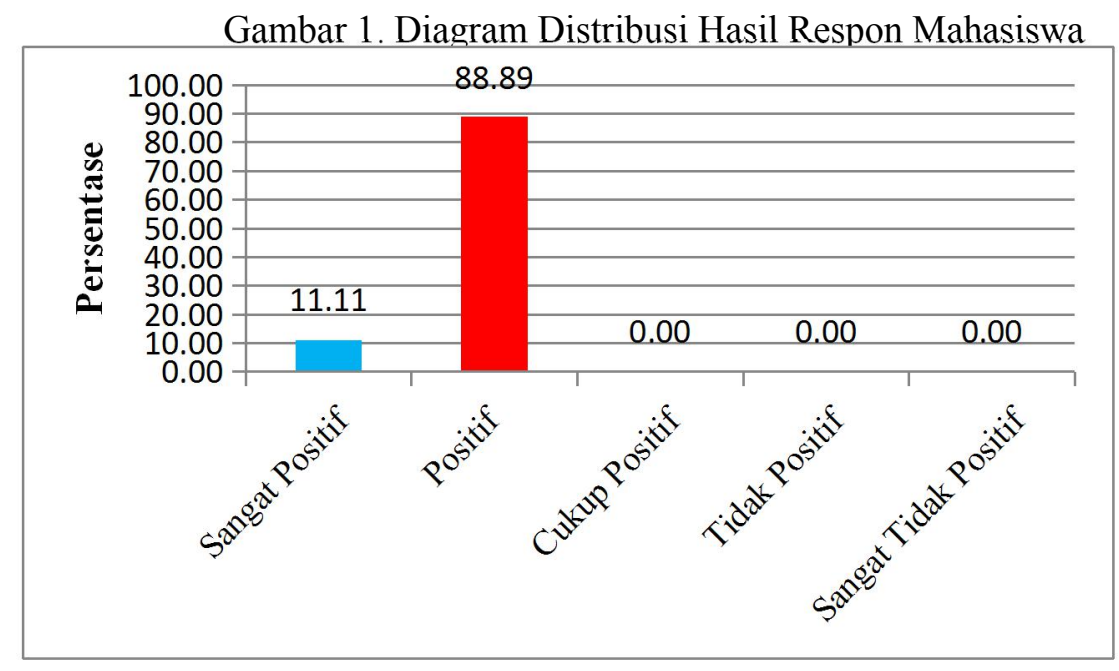

Berdasarkan hasil respon mahasiswa pada Gambar 1. terlihat bahwa sebagian besar mahasiswa merespon positif pengembangan modul yaitu sebanyak 24 orang atau $88,89 \%$, dan sangat positif 3 orang atau $11,11 \%$. Penilaian ini menginformasikan bahwa modul mikrobiologi dengan menggunakan jurnal ilmiah sebagai sumber belajar memberikan dampak positif pada kegiatan pembelajaran. c. Respon Pengajar

Analisis respon pengajar terhadap pengembangan modul bertujuan untuk mengetahui respon pengajar terhadap modul mikrobiologi dengan menggunakan jurnal ilmiah sebagai sumber belajar yang mencakup aspek petunjuk, aspek isi, aspek kebahasan, dan aspek tata grafik. Adapun hasil respon pengajar disajikan pada Gambar 2. berikut ini. 
Gambar 2. Diagram Distribusi Hasil Respon Mahasiswa



Berdasarkan Gambar 2. menunjukkan pengajar merespon dengan baik keseluruhan aspek dalam modul pembelajaran.

\section{d. Tes Hasil Belajar \\ Hasil tes belajar dijadikan sebagai tolak ukur untuk mengetahui kemampuan}

mahasiswa dalam menguasai materi yang terdapat dalam modul mikrobiologi dengan menggunakan jurnal ilmiah sebagai sumber belajar. Perolehan tes hasil belajar mahasiswa disajikan pada Tabel 10. Berikut ini.

Tabel 10. Hasil Belajar Mahasiswa

\begin{tabular}{cc}
\hline Variabel & Nilai Statistik \\
\hline Subjek Penelitian & 27 \\
\hline Skor Ideal & 25 \\
\hline Rata-rata nilai & 75,41 \\
\hline Nilai maksimum & 88 \\
\hline Nilai minimum & 64 \\
\hline $\begin{array}{c}\text { Jumlah mahasiswa yang memenuhi standar } \\
\text { nilai }\end{array}$ & 24 \\
\hline $\begin{array}{c}\text { Jumlah mahasiswa yang tidak memenuhi } \\
\text { standar nilai }\end{array}$ & 3 \\
\hline
\end{tabular}

Berdasarkan penilaian tes hasil belajar mahasiswa pada Tabel 10. menunjukkan perolehan rata-rata nilai dari 27 mahasiswa yaitu 75,41 dengan nilai tertinggi 88 dan nilai terendah 64. Jumlah mahasiswa yang memenuhi standar penilaian pembelajaran sebanyak 24 orang dan 3 orang tidak memenuhi standar penilaian mata kuliah mikrobiologi.

\section{Pembahasan}

Adapun pembahasan dari hasil penelitian ini meliputi tiga aspek yaitu kevalidan, kepraktisan, dan keefektifan yang dijabarkan berikut ini:

\section{Kevalidan}

Berdasarkan Tabel 5. terdapat saran ahli terhadap modul pembelajaran pada aspek cakupan isi diantaraya, a) sistematika penulisan harus terstruktur dengan baik agar memudahkan peserta didik mempelajari modul, b) sumber materi modul harus diberi warna agar memudahkan mahasiswa membedakan materi yang diperoleh dari jurnal ilmiah maupun dari buku, dan c) daftar pustaka harus diletakkan pada bagian akhir modul sehingga tidak terjadi pengulangan nama penulis. Adapun saran ahli terhadap satuan acara perkuliahan atau SAP yaitu SAP dibuat per pokok bahasan agar materi pembelajaran dapat terarah pada pokok bahasan yang diajarkan. Saran tersebut sejalan dengan Oemar (2010) bahwa satuan acara perkuliahan merupakan panduan pengajar dalam menyajikan dan mengarahkan materi pembelajaran kepada para peserta didik guna mencapai tujuan pembelajaran.

Selanjutnya, saran ahli terhadap tes hasil belajar yaitu mengoreksi kalimat soal sehingga tidak menimbulkan penafsiran ganda dalam menjawab. Hal tersebut sesuai dengan pendapat Suharsimi (2008) bahwa soal yang baik harus memenuhi syarat bahasa yang baku sesuai dengan kaidah bahasa Indonesia, lugas 
dan tidak menimbulkan penafsiran ganda atau jamak. Demikian saran ahli terhadap keseluruhan instrumen penelitian, maka tahap berikutnya dilakukan perbaikan sehingga diperoleh perangkat bahan ajar yang memiliki derajat validitas yang baik dan layak digunakan.

\section{Kepraktisan}

Berdasarkan hasil penilaian pada Tabel 8. rata-rata pengajar mampu melaksanakan setiap fase kegiatan pembelajaran dengan baik dengan perolehan kategori sangat tinggi. Pada kegiatan awal secara keseluruhan telah memenuhi kriteria kepraktisan dengan rata-rata 3,75 atau sangat tinggi. Hasil ini menginformasikan bahwa pengajar dapat melaksanakan seluruh kegiatan awal dengan baik, diantaranya pengajar mampu menyampaikan deskripsi singkat materi dan tujuan pembelajaran. Hasil tersebut sejalan dengan Darmadi (2009) bahwa kegiatan awal pembelajaran dilaksanakan agar peserta didik dapat menyiapkan mental, memotivasi diri, dan mengonstruksi pemahamannya agar ikut terlibat dalam persoalan pembelajaran serta dapat memusatkan perhatian pada materi pelajaran.

Pada kegiatan inti rata-rata telah memenuhi kriteria kepraktisan. Hasil ini menginformasikan bahwa pengajar mampu melaksanakan seluruh rangkaian kegiatan inti dengan baik, diantaranya pengajar dapat menerapkan metode pembelajaran langsung dan model pembelajaran kelompok, agar mahasiswa aktif memecahkan persoalan pembelajaran, dan membantu sesama teman dalam memahami materi.

Pada kegiatan akhir secara keseluruhan telah memenuhi kriteria kepraktisan dengan perolehan rata-rata 3,83 atau sangat tinggi. Hasil ini menunjukkan bahwa pengajar dapat melaksanakan seluruh rangkaian kegiatan akhir dengan baik, dimana pengajar mampu mengarahkan mahasiswa merangkum materi dan memberikan penghargaan pada kelompok diskusi yang menyajikan materi dengan baik.

Selanjutnya berdasarkan Tabel 8. hasil pengelolaan suasana kelas rata-rata telah memenuhi kriteria kepraktisan dengan nilai rata-rata 3,6 atau sangat tinggi. Secara empirik hasil ini menunjukkan bahwa mahasiswa dan pengajar antusias menggunakan modul, sebab modul yang dikembangkan disusun secara spesifik dengan menerapkan metode dan model pembelajaran yang sesuai. Hasil ini sejalan dengan Prastowo (2010) bahwa modul yang dirancang dengan baik mampu memberikan manfaat bagi peserta didik dan pengajar, dimana dapat memfasilitasi peserta didik sesuai dengan kebutuhan pembelajaran serta membantu pengajar mengordinir dan menciptakan situasi kelas yang kondusif.

\section{Keefektifan}

Bahan ajar dikatakan efektif apabila memenuhi kriteria penilaian dari masingmasing komponen keefektifan meliputi aktivitas mahasiswa, respon mahasiswa, respon pengajar dan tes hasil belajar. Berikut penjelasan mengenai komponen keefektifan bahan ajar.

a) Aktivitas mahasiswa

Berdasarkan Tabel 9. pada pertemuan I sebanyak $88,89 \%$ yang aktif memperhatikan pembelajaran, sementara pertemuan II $81,48 \%$, dan pertemuan III $85,19 \%$. Hasil ini menginformasikan bahwa telah memenuhi penilaian keefektifan karena secara keseluruhan mahasiswa turut aktif mengikuti pembelajaran dan menyimak materi dengan baik. Hal ini sejalan dengan Majid (2007) bahwa memperhatikan pelajaran dapat menciptakan suasana yang memungkinkan peserta didik turut terlibat aktif dalam pembelajaran, menumbuhkan kesiapan peserta didik untuk belajar, dan dapat menyesuaikan diri dengan materi.

Berdasarkan Tabel 9. pada pertemuan I sebanyak $40.74 \%$ yang aktif bekerja kelompok dimana hasil ini tidak memenuhi keefektifan karena hanya dua kelompok yang siap mempresentasikan materi. Sementara pada pertemuan II sebanyak 59,26\%. Hasil tersebut memenuhi penilaian keefektifan karena yang mempresentasikan materi lebih banyak dari pertemuan sebelumnya. Selanjutnya pada pertemuan III sebanyak $100 \%$ yang aktif bekerja kelompok karena masing-masing kelompok sangat siap mempresentasikan materi diskusi pembelajaran. Hasil kegiatan ini sejalan dengan Ratna (2013) bahwa bekerja sama dalam kelompok memberikan kesempatan kepada semua peserta didik dan melibatkan secara aktif dalam proses berpikir untuk mencapai ketuntasan materi dan ketuntasan belajar.

Berdasarkan Tabel 9. pada pertemuan I dan II sebanyak $37,04 \%$ dan pertemuan III sebanyak $44 \%$ yang aktif berdiskusi. Hasil ini termasuk kategori sangat rendah, atau tidak memenuhi penilaian keefektifan karena kurangnya mahasiswa yang terlibat aktif 
berdiskusi memberikan ide pemikiran, dan bertukar pendapat dalam kegiatan diskusi.

Berdasarkan Tabel 9. pada kegiatan aktif memberikan pertanyaan dengan hasil pertemuan I sebanyak $44,44 \%$, pertemuan II $29,63 \%$ dan pertemuan III $22,22 \%$. Hasil ini dinilai tidak memenuhi penilaian keefektifan karena kurangnya mahasiswa memberikan dan menjawab pertanyaan selama kegiatan diskusi. Menurut Darmadi (2010) bahwa pada hakikatnya peserta didik yang memberikan pertanyaan akan mendapatkan umpan balik mengenai informasi yang ingin diketahui serta menunjukkan interaksi yang dinamis dan multi arah sehingga kegiatan pembelajaran berjalan secara kondusif.

Berdasarkan Tabel 9. pada aktivitas menjawab pertanyaan, pertemuan I sebanyak $37,04 \%$, pertemuan II $25,93 \%$, dan pertemuan III 33,33\%. Hasil ini termasuk kategori sangat rendah karena hanya sebagian kecil mahasiswa yang aktif memberikan pemikiran, ide, dan sanggahan dalam menyelesaikan permasalahan atau kesulitan mempelajari materi modul. Hal ini sejalan dengan pendapat Trianto (2007) bahwa dalam menjawab pertanyaan diskusi pendapat atau gagasan harus sesuai dengan topik, bersifat logis yang disertai alasan-alasan, bukti dan fakta sehingga pendapat yang dikemukakan dapat meyakinkan peserta serta mampu memecahkan kesulitan dalam proses pembelajaran.

Berdasarkan Tabel 9. pada kegiatan membuat kesimpulan menunjukkan pertemuan I sebanyak $40 \%$ aktif memberikan kesimpulan diakhir presentasi. Hasil ini menginformasikan bahwa tidak memenuhi penilaian keefektifan karena dari lima kelompok diskusi hanya dua kelompok diskusi yang memberi kesimpulan materi. Sementara pertemuan II sebanyak $60 \%$ aktif dimana hasil tersebut memenuhi kriteria keefektifan. Selanjutnya pada pertemuan III sebanyak $100 \%$ aktif memberikan kesimpulan karena semua kelompok diskusi memberikan kesimpulan materi pada akhir diskusi. Aktivitas ini sejalan dengan Wenno (2010) bahwa kegiatan merangkum atau membuat garis besar materi yang baru dibahas akan mengkonsolidasikan perhatian peserta didik pada hal-hal pokok pelajaran dan mengorganisasikan semua kegiatan dan pelajaran menjadi satu kebulatan yang bermakna untuk memahami esensi pelajaran itu. b) Respon mahasiswa

Respon mahasiswa dikatakan
memenuhi kriteria keefektifan jika
mendapatkan kategori positif $>50 \%$
Berdasarkan hasil respon mahasiswa terhadap modul pada Gambar 1. sebanyak $88,89 \%$ merespon positif dan $11,11 \%$ merespon sangat positif. Hasil ini menunjukkan bahwa modul mikrobiologi dapat menarik perhatian mahasiswa karena modul yang disajikan dilengkapi dengan gambar yang jelas dan berwarna, serta membantu mahasiswa memahami pelajaran secara spesifik. Sejalan dengan Oktavia (2012) bahwa keefektifan modul pembelajaran dipengaruhi beberapa hal diantaranya motivasi, respon peserta didik terhadap materi pelajaran dan kesanggupan peserta didik dalam memahami pelajaran.

\section{c) Respon pengajar}

Respon pengajar dikatakan memenuhi kriteria keefektifan jika mendapatkan respon positif $>50 \%$. Berdasarkan hasil respon pengajar pada Gambar 2. secara keseluruhan pengajar merespon cukup baik modul mikrobiologi dengan penilaian 20,83\%, sementara $54,17 \%$ merespon baik dan $25,00 \%$ merespon sangat baik. Hasil ini menginformasikan bahwa modul mikrobiologi dengan menggunakan jurnal ilmiah sebagai sumber belajar efektif digunakan dalam pembelajaran, dimana pengajar memberikan penilaian positif pada semua aspek modul diantaranya aspek petunjuk, aspek isi, aspek kebahasan dan aspek lay out. Sejalan dengan pendapat Chomsin (2008) bahwa kriteria modul yang baik yaitu 1) modul harus disusun secara rasional sesuai dengan kompetensi dasar yang harus dicapai oleh peserta didik setelah menguasai modul, 2) memuat indikator agar peserta didik dapat mengetahui secara jelas hasil belajar menjadi tujuan pembelajaran, 3) isi modul harus merupakan bahan terkini sesuai dengan tuntutan perkembangan yang memuat contoh dan latihan yang relevan sehingga peserta didik dapat mengerti mengenai materi yang dipelajari, 4) penulisan modul harus mengacu pada kaidah penulisan yang benar, dan 5) Referensi yang dipergunakan tidak lebih 10 tahun sebelum modul ditulis.

d) Tes hasil belajar

1) Tes hasil belajar dilaksanakan pada akhir proses kegiatan pembelajaran dengan maksud untuk mengetahui keefektifan modul dalam mencapai tujuan pembelajaran. Keefektifan modul 
pembelajaran ditentukan melalui hasil belajar mahasiswa dalam mencapai standar penilaian mata kuliah mikrobiologi yang ditetapkan oleh pengajar yaitu 70 . Berdasarkan data statistik hasil belajar mahasiswa pada Tabel 10 . rata-rata mahasiswa memperoleh nilai 75, 41 dengan jumlah mahasiswa sebanyak 24 orang. Hal ini berarti mahasiswa yang mencapai standar penilaian lebih banyak dari yang tidak memenuhi standar penilaian. Hasil tersebut menunjukkan bahwa pembelajaran dengan menggunakan modul mikrobiologi sangat efektif bagi mahasiswa dimana mahasiswa dapat menguasai materi modul mikrobiologi dengan menggunakan jurnal ilmiah sebagai sumber belajar dengan baik. Penilaian tes belajar ini sejalan dengan penelitian Oktavia (2012) yang menjelaskan bahwa keefektifan dalam menggunakan modul pembelajaran dapat dilihat dari rata-rata nilai hasil belajar yang diperoleh peserta didik yaitu minimal 70 yang menunjukkan tingkat penguasaan peserta didik terhadap materi pembelajaran. Pendapat tersebut senada dengan Sri (2011) menjelaskan bahwa hasil belajar merupakan hasil akhir dari proses kegiatan belajar peserta didik dari seluruh kegiatan pembelajaran di kelas, menerima pelajaran untuk mencapai kompetensi, diukur dengan alat penilaian berupa tes evaluasi dengan hasil dinyatakan dalam bentuk nilai untuk mengetahui kemampuan peserta didik.

\section{KESIMPULAN \& SARAN}

Berdasarkan rumusan masalah penelitian telah menunjukkan kualitas modul mikrobiologi menggunakan jurnal ilmiah sebagai sumber belajar ditinjau dari segi kevalidan, kepraktisan, dan keefektifan, kualitas dari modul pembelajaran yang dicapai yaitu:

1. Memenuhi kriteria kevalidan dengan perolehan rata-rata penilaian dari ahli terhadap modul pembelajaran, SAP, dan tes hasil belajar yaitu sangat valid dan sedikit revisi.

2. Memenuhi kriteria kepraktisan yang dilihat dari cara pengelolaan pembelajaran oleh pengajar dengan perolehan penilaian sangat tinggi pada setiap aspek kegiatan pembelajaran.

3. Memenuhi kriteria keefektifan yang dinilai berdasarkan aktivitas mahasiswa yang terlaksana, respon mahasiswa dan respon pengajar terhadap modul yang memperoleh penilaian positif, dan tes hasil belajar mahasiswa yang menunjukkan sebagian besar memenuhi standar penilaian pembelajaran.

Berikut ini beberapa saran yang diharapkan dapat membantu penelitian selanjutnya:

1. Diharapkan kepada peneliti agar melanjutkan penelitian dan pengembangan modul mikrobiologi menggunakan jurnal ilmiah sebagai sumber belajar pada konsep pengelompokkan bakteri dan jamur secara luas.

2. Diharapkan kepada pendidik, agar melanjutkan menggunakan modul mikrobiologi pada pokok bahasan pengelompokkan bakteri dan jamur, karena ditinjau dari segi informasi sumber belajar yang digunakan lebih terkini dari buku paket.

\section{DAFTAR PUSTAKA}

Adikasimbar. 2010. Pedoman Umum Pengembangan Bahan Ajar. Makalah online. Jakarta. Diakses 20 November 2013

Arief, S. 2004. Pendayagunaan Teknologi Informasi dan Komunikasi untuk Pembelajaran. Makalah Online. Diakses 20 November 2013

Arifin, S. 2011. Sukses Menulis Buku Ajar dan Referensi. Surabaya: Grasindo

Chomsin, S \& Jasmadi. 2008. Panduan Menyusun Bahan Ajar Berbasis Kompetensi. Jakarta: PT. Elex Media Komutindo.

Depdiknas. 2007. Pengembangan Bahan Ajar. Jakarta

Depdiknas. 2008. Pedoman Pengembangan Bahan Ajar. Jakarta: Direktorat Pembinaan SMA. Dirjen Mandikdasmen. Depdiknas.

Degeng, I. 1993. Media Pendidikan. Malang: FIP IKIP Malang.

Dewiyanti, F. 2011. Pengembangan Modul Pembelajaran Kesetimbangan dalam Larutan Berbasis Konstruktivistik bagi Siswa MAN 2 Model Makassar. Disertasi tidak diterbitkan. Makassar: PPs UNM.

Darmadi, H. 2010. Kemampuan Dasar Mengajar (Landasan dan Kosep Implementasi). Bandung: Alfabeta.

Faizah, L. 2010. Pemanfaatan Bahan Ajar Lembar Kerja Siswa (LKS) Untuk Meningkatkan Efektivitas Pembelajaran Pendidikan Agama Islam. Skripsi. 
Diterbitkan. Malang: Universitas Islam Negeri Malik Ibrahim, Diakses 12 Oktober 2013

Ginting, A. 2008. Esensi praktis Belajar dan Pembelajaran. Bandung: Humaniora

Gusti. 2013. Pengembangan Modul Pembelajaran Fisika Berorientasi Model Daur Belajar (Learning Cycle). (Jurnal Online), (http://fkipunjaok.com), Diakses 16 Desember 2013

Irmaningtyas. 2013. Pengembangan Modul Biologi dengan Model Siklus Belajar untuk Meningkatkan Kompetensi Siswa. (Jurnal Online), (http://jurnal- online.um.ac.id,

Diakses 16 Desember 2013)

Majid, A. 2007. Perencanaan Pembelajaran Mengembangkan Standar Kompetensi Guru. Bandung: PT. Remaja Rosdakarya.

Mansur \& Rasydin. H. 2009. Penilaian Hasil Belajar. Bandung: CV. Wacana Prima.

Nurhayati, B. 2011. Strategi Belajar Mengajar. Makassar: Badan Penerbit Universitas Negeri Makassar.

Nurdin, 2007. Model Pembelajaran Matematika yang Menumbuhkan Kemampuan Metakognitif untuk Menguasai Bahan Ajar. Disertasi tidak diterbitkan. Surabaya: PPs UNESA.

Nurkanca, W. 2009. Evaluasi Hasil Belajar. Surabaya: Usaha Nasional

Oktavia, S \& Iqma, N. Efektivitas Penerapan Modul Materi Analisis Elektornikimia Berbasis Inkuiri Terbimbing Terhadap Hasil Belajar. (Online). (http://um.ac.id) Diakses 17 Juli 2014.

Oemar, Hamalik. 2010. Kurikulum dan Pembelajaran. Jakarta; Bumi Aksara

Patkur, M. 2013. Pengembangan Modul Pembelajaran untuk Meningkatkan Efektifitas Pembelajaran Siswa. (online). (http://undana.ac.id) Diakses 17 juli 2014

Prawiradilaga, D. S. 2008. Prinsip Disain Pembelajaran. Jakarta: Kencana, Prenada Media Group.

Prastowo, A. (2012). Panduan Kreatif Membuat Bahan Ajar Inovatif. Yogyakarta: DIVA Press.

Pujayanto \& Budihart, R. \& Oni, A. 2013. Pengembangan Bahan Ajar Ip Terpadu Berbasis Saling Temas Dengan Tema Biomassa Sumber Energi Alternatif Terbarukan. Jurnal
Pendidikan Fisika. (Online), Vol.1, No.1, Diakses 14 Desember 2013.

Putu, S. J. 2012. Pengembangan Modul Fisika Kontekstual untuk Meningkatkan Hasil

Belajar Fisika. (Online), Vol. 1, No. 2 (http://pasca.undiksha.ac.id)

Diakses 16 Desember 2013.

Pelzar, M. J. 2007. Dasar-Dasar Mikrobiologi. Jakarta: UI Press

Ratna, W. 2013. Pengembangan Modul Berorientasi POE (Predict, Observe, Explain) Berwawasan Lingkungan pada Materi Pencemaran untuk Meningkatkan Hasil Belajar

Siswa. (Online). (http://pasca.uns.ac.id) Diakses 17 Desember 2013.

Ruhimat, T. 2009. Prosedur Pembelajaran. (Jurnal Online). (http://file.upi.edu/Direktori/pdf, Diakses 16 Desember 2013)

Rusli, 2012. Pengembangan Perangkat Pembelajaran Berbasis Kooperatif. Tesis. Tidak diterbitkan. Makassar: Program Pascasarjana UNM.

Sanjaya, W. 2008. Perencanaan dan Desain Sistem Pembelajaran. Jakarta: Kencana, Prenada Media Group.

Santyasa, I. W. 2007. Landasan Konseptual Media Pembelajaran. Bandung: Universitas Pendidikan Ganesha.

Santoso, N. 2000. Penyiapan Bahan Ajar. Makalah online (http://staff.uny.ac.id/PenyiapanBahan-AJAR.pdf), Diakses 20 November 2013.

Setiawan, 2009. Pelayanan Rujukan/Referensi. Makalah Online. Diklat Depok Tanggal 21 April 2009.

Sugiyono, 2008. Metode Penelitian Pendidikan. Bandung: Alfabeta.

Sudijono, 2012. Pengantar Evaluasi Pendidikan. Jakarta: Rajawali Pers.

Sri, R. 2012. Penerapan Model Pembelajaran ASSURE Untuk Meningkatkan Hasil IPA Siswa. (Online), Vol. 2, No. 1 (http://repository.library.uksw.edu) Diakses 14 Desember 2013.

Sukmadinata, N. S. 2012. Metode Penelitian Pendidikan. Bandung: Remaja Rosdakarya.

Siddiq, D. 2008. Pengembangan Bahan Ajar. Direktorat Jenderal Pendidikan Tinggi DEPDIKNAS.

Sofiyah, 2010. Pengaruh Model Pengajaran Langsung (Direct Teaching) Terhadap Hasil Belajar. Fakultas Ilmu Keguruan 
\& Tarbiyah. Universitas Islam Negeri Jakarta.

Trianto. 2007a. Model Pembelajaran Terpadu dalam Teori dan Praktek. Jakarta: Prestasi Pustaka

Wenno, I. 2010. Pengembangan Model Modul IPA Berbasis Problem Solving Method Berdasarkan Karakteristik Siswa dalam Pembelajaran. Jurnal Cakrawala Pendidikan. (Online), Vol. 2, No. 2 (http://journal.uny.ac.id) Diakses 17 Desember 2013

Wulan, R. S. 2013. Pengembangan Modul Biologi Berbasis Inkuiri Terbimbing pada Materi Pokok Ekosistem. Skripsi Online. (http://digilib.uinsuka.ac.id/7309/) Diakses 16 Desember 2013.

Widodo, C. S. \& Jasmadi. 2008. Panduan Menyusun Bahan Ajar Berbasis Kompetensi. Jakarta: PT Elex Media Komputindo.

Yasa, G. A. A. 2012. Pengembangan Bahan Ajar Online Mata Kuliah Micro Teaching dengan Model Borg \& Gall. Jurnal Ilmu Pendidikan, (online), (http://pasca.undiksha.ac.id/e-journal/, Diakses 25 November 2013). 